\title{
Evidence on the advantages of low carbon growth in Jordan
}

Roz Price

Institute of Development Studies

6 August 2021

\section{Question}

- Is there any Jordan specific research out there that looks at evidence for the advantage of low carbon growth over high carbon growth?

\section{Contents}

1. Summary

2. Economic impacts of climate change in Jordan

3. Economic advantages to green growth in Jordan

4. References

The K4D helpdesk service provides brief summaries of current research, evidence, and lessons learned. Helpdesk reports are not rigorous or systematic reviews; they are intended to provide an introduction to the most important evidence related to a research question. They draw on a rapid deskbased review of published literature and consultation with subject specialists.

Helpdesk reports are commissioned by the UK Foreign, Commonwealth, \& Development Office and other Government departments, but the views and opinions expressed do not necessarily reflect those of FCDO, the UK Government, K4D or any other contributing organisation. For further information, please contact helpdesk@k4d.info. 


\section{Summary}

There has been a considerable amount of research generally into the benefits associated with low carbon development, showing that it can be synergistic with development priorities - such as job creation, improved public health, social inclusion and improved accessibility (see for example, Gouldson et al., 2018). However, this rapid review finds limited evidence and information around these benefits specifically for the Hashemite Kingdom of Jordan (henceforth referred to as Jordan in this paper). Despite Jordan being one of the most active and pioneering countries in the Middle East and North African region on climate change and papers referencing the many benefits of low carbon development and green growth in Jordan generally (for example, the papers of the Green Growth Institute (GGGI)), few provide clear projected economic data and evidence. This indicates that a knowledge gap exists.

There has been much interest in green growth in Jordan in the last ten years, particularly as Jordan is seen as having a large renewable energy potential for solar and wind. International organisations have been working with Jordan to develop comprehensive national plans and strategies to encourage green growth investment, in particular, the GGGI. Within the Jordanian government, the green growth concept has mainly been promoted by the Ministry of Environment. With the added impacts of the Covid-19 pandemic, there are fresh calls for Jordan to move away from its current growth model, which yields low investment, high debt and slow reform implementation, towards an investment and export-driven and resource-efficient growth model. ${ }^{1}$ However, the bulk of literature has focused on defining green growth and identifying potential investment projects for green growth in Jordan. There is little literature on specific economic metrics and findings in relation to the benefits of green growth for Jordan. Furthermore, data availability and reliability is a major constraint for green growth diagnostics at sectoral or industrial levels in Jordan (Engelmann et al., 2019).

The World Bank in particular has produced a number of reports that have fed into this review, that explore or touch on green growth in Jordan - however, they themselves recognise that there is a lack of research on the economic and job-generating impacts of a green growth pathway in Jordan, and emphasise the need for further analysis (see specifically Hakim et al., 2017). Many of the green growth statistics referenced are from single reports undertaken a number of years ago - for example, that environmental degradation costs Jordan $2 \%$ of its GDP per year comes from a World Bank report written in 2010 and based on data from 2006 (World Bank, 2010). No more recent reviews were found during this rapid review. This review draws on a mixture of academic and grey literature from government and international organisations. Literature searches were concentrated in key databases and search engines, including the World Bank's document repository, Jordan specific webpages from the UN system and bilateral donors.

This rapid review first highlights a small number of findings in relation to the economic impacts and costs of climate change in Jordan and environmental degradation. There are a few studies looking at the costs of climate change, however, economic estimates of environment degradation costs (put at $2.35 \%$ of GDP) are based on research from 2010 . The costs associated with $3^{\circ} \mathrm{C}$ of climate change have been estimated for Jordan, with impacts resulting in negative GDP growth compared to the base year of 2017 of $-0.555 \% /$ year by 2047 and $-3.254 \% / y e a r$ by 2100 . The final section

\footnotetext{
${ }^{1}$ See for example https://mop.gov.jo/EN//NewsDetails/Joint_Statement_on_the_World_Bank_Group_\%E2\%80\% 94_Jordan_Partnership [accessed 06/08/2021]
} 
explores the evidence on the economic advantages of following a green growth pathway in Jordan. However, although Jordan has a number of environmental and climate related policies and strategies, including a National Green Growth Plan and National Action Plan, "evidence" or data both for country-wide and sector-specific economic benefits of a low carbon pathway was largely lacking (for example, where job creation may occur, the specific health impacts, or where poverty reduction will occur). Nevertheless, this section provides some evidence in relation to the economic benefits of greening housing, investing in renewable energy and greening the water sector in Jordan. Little information was found in the course of this review around gender dimensions of low carbon development in Jordan or in relation to the most vulnerable - such as those with disabilities.

\section{Economic impacts of climate change in Jordan}

Jordan is one of the most water-scarce countries in the world. It has experienced rapid population growth with an estimated increase of $87 \%$ from 2004 (at about 5 million) to 2015 (at about 9.5 million), mainly due to the influx of refugees from Syria. Hence, Jordan's cities have experienced rapid urbanisation, and Jordan is considered one of the most urbanised countries in the world with about $90 \%$ of the population living in urban areas. Poverty and unemployment (especially among young people) are two of the most important challenges the country is facing (CAPSUS, 2018: 6). Furthermore, Jordan has faced a steep increase in water demand in recent years as a result of its rapid population growth, income growth, and urbanisation (Hakim et al., 2017). A decrease of $20 \%$ in annual precipitation over the last few decades coupled with this increasing demand and inefficient use of water has exacerbated stress in Jordan's water resources. With Jordan's population expected to double by 2050 , this will further increase pressure on natural resources and infrastructure, especially water resources (Engelmann et al., 2019).

\section{Costs of climate change impacts}

The World Bank's Systematic Country Diagnostic for Jordan underscores water and climate change as the main constraints to eradicating extreme poverty and promoting shared prosperity in a sustainable way in addition to energy, natural resources and the environment (Hakim et al., 2017: 26; World Bank Group, 2016).

Kompas et al. (2018) used a large dimensional intertemporal computable general equilibrium (CGE) trade model to account for the various effects of global warming (e.g., loss in agricultural productivity, sea level rise, and health effects) on Gross Domestic Product (GDP) growth and levels for 139 countries. The authors note that there are a number of limitations with the model, especially that it is not possible to include the effects of natural disasters or more extreme weather events that occur year to year in the model. Nevertheless, the estimates from the model do indicate substantial damages and losses in national income from climate change and provide a means of comparison across different temperature ranges and countries. For Jordan, they found that the impacts of $3^{\circ} \mathrm{C}$ warming would result in negative GDP growth compared to the base year of 2017 in both the medium and long term (see table 1). Kompas et al. (2018) also compute the long-run impacts of different global warming scenarios $\left(1-4^{\circ} \mathrm{C}\right)$, which correspond to different Representative Concentration Pathways (RCPs). The results can be seen in Table 2 and the measure is the change in GDP. 
Table 1: The effects of climate change $\left(3^{\circ} \mathrm{C}\right.$ warming $)$ on Jordan's GDP

\begin{tabular}{|l|l|l|l|l|l|}
\hline & 2027 & 2037 & 2047 & 2067 & $\begin{array}{c}\text { Long run } \\
(2100)\end{array}$ \\
\hline GDP (\% Change/Year) & -0.158 & -0.342 & -0.555 & -1.052 & -3.254 \\
\hline
\end{tabular}

Source: Kompas et al., 2018: 1163

Table 2: Long-run impacts of climate change scenarios on Jordan's GDP

\begin{tabular}{|c|c|c|c|c|}
\hline & $1^{\circ} \mathrm{C}$ & $2^{\circ} \mathrm{C}$ & $3^{\circ} \mathrm{C}$ & $4^{\circ} \mathrm{C}$ \\
\hline GDP (\% Change/Year) & -0.982 & -1.998 & -3.254 & -4.835 \\
\hline
\end{tabular}

Source: Kompas et al., 2018: 1167

\section{Costs of environmental degradation}

A 2010 World Bank report was identified that looked at the costs of environmental degradation in Jordan, however, no recent reports (less than 5 years old) were identified in this rapid review (World Bank, 2010).

The 2010 World Bank study took into account both immediate and longer-lasting impacts of environmental damage in Jordan for the year 2006. This estimated the total cost of environmental degradation to be in the range of Jordanian Dinar (JD) 143-332 million, with an average of JD237 million (US\$360 million), or 2.35\% of GDP in 2006 (World Bank, 2010: 5). If the impact of emissions on the global environment were to be added, then the total cost to Jordan and the global community as a whole would be JD393 million (US\$590 million). The most important contributor was air pollution, which accounted for $1.15 \%$ of GDP - although the relatively high cost of outdoor air pollution should be interpreted as a signal of degradation in selected road traffic and industrial hot spots rather than overall national poor air quality. The impact of inadequate water supply, sanitation and hygiene formed the second most significant factor in 2006, representing about $0.81 \%$ of GDP. The cost of the improper disposal of solid waste ranked third, followed by the environmental damage to soil conditions and the coastal zone (World Bank, 2010: 5). The World Bank's 2016 Systematic Country Diagnostic for Jordan highlights that although Jordan's aggregate cost of environmental degradation as a percent of GDP equivalent is low compared to the mean (just under $8 \%$ ), it also starts with a much leaner basket of environmental assets (World Bank Group, 2016: 50).

\section{Economic advantages to green growth in Jordan}

There exists several indicator-based assessments in the form of macroeconomic diagnostics or indices for green growth (Engelmann et al., 2019: 8). The GGGl's Green Growth Index is a composite index measuring a country's performance in achieving sustainability targets including Sustainable Development Goals (SDGs), Paris Climate Agreement, and Aichi Biodiversity Targets 
for four green growth dimensions - efficient and sustainable resource use, natural capital protection, green economic opportunities, and social inclusion. ${ }^{2}$ The 2020 Green Growth Index reported that although the Index has generally increased worldwide from 2005 to 2019, a number of countries experienced a decline in green growth performance over this period. Specifically, Jordan experienced a $15 \%$ decline in scores - putting it in the top six countries with the most significant declines out of 117 countries (Acosta et al., 2020: 12).

Jordan has a number of environmental and climate related policies and strategies, including a National Green Growth Plan and National Action Plan that were produced in collaboration with the Global Green Growth Institute (GGGI). ${ }^{3}$ However, although the documents have undertaken more than 20 cost-benefit analyses (CBAs) for priority projects identified across six priority sectors ${ }^{4}$ (see Ministry of Environment, 2017: 4), the GGGI documents do not provide "evidence" or data on the country-wide economic benefits of a low carbon pathway for Jordan (for example, where job creation may occur, the specific health impacts, or where poverty reduction will occur). Data availability and reliability is a major constraint for green growth diagnostics at sectoral or industrial levels in Jordan (Engelmann et al., 2019).

A key document identified during this rapid review is a World Bank Jordan Economic Monitor from Spring 2017, that includes a special focus section on "the green economic boost" in Jordan (Hakim et al., 2017). It emphasises the need for further analysis to quantify the economic and jobgenerating impact from pursuing a green growth agenda (Hakim et al., 2017: 30). The paper recognises that Jordan has a strong economic argument to follow a low carbon development pathway, although transition costs are likely to be high and will have to be carefully managed. It argues that green growth could support a reduction in the fiscal burden of dependence on commodity imports (oil and gas) in international markets, which would bring additional stability to the budget due to a lower exposure to the fluctuation of commodity prices. This could also support better debt management leading to an enhanced credit rating for Jordan and a reduction in its cost of funding. The stimulation of economic growth could stem from the attraction of Foreign Direct Investment (FDI) for the development of infrastructure projects, which would in turn contribute to the involvement of the local workforce and the development of human capital. However, the paper emphasises that such effects need to be modelled and quantified, especially the potential short term costs of transition towards a low-carbon, green economy (Hakim et al., 2017: 30).

\section{Green jobs estimates}

A key estimate around job creation that is referenced in many other reports (and by the Jordanian government) comes from a 2011 United Nations Environment Programme commissioned report on a green economy in Jordan, which states that "investment in environmental conservation could generate an estimated 50,000 jobs, and over JD 1.3 billion in revenues over a period of 10 years" in Jordan (Enconsult Jordan, 2011). Table 3 below gives a breakdown of this data by sector. The

\footnotetext{
2 See https://greengrowthindex.gggi.org/\#introduction

3 GGGI defines green growth "as a development approach that delivers economic growth that is both environmentally sustainable and socially inclusive" (GGGI, 2020: 9).

4 The Green Growth Plan for Jordan was launched in May 2017 and focuses on energy, water, waste, transport, tourism and agriculture sectors.
} 
calculations for these estimates are given in more detail in the report, but most are based on global estimates applied to the Jordan experience (see Enconsult Jordan, 2011).

Table 3: Jobs and investment generated per sector in Jordan

\begin{tabular}{|c|c|c|c|}
\hline Sector & Green jobs created & $\begin{array}{l}\text { Investments } \\
\text { million) }\end{array}$ & Time period \\
\hline Renewable energy & 3,000 & 620 & $2010-2020$ \\
\hline Transport & 9,500 & 130 & $2010-2020$ \\
\hline Water & 31,000 & 330 & \\
\hline Waste management & 3,000 & 41 & \\
\hline Organic agriculture & 1,700 & 111 & $2010-2020$ \\
\hline Sustainable tourism & 3,900 & 89 & Annually \\
\hline Total: & 51,100 & 1,321 & \\
\hline
\end{tabular}

Source: Enconsult Jordan, 2011: 27

\section{Urban growth scenarios}

The World Bank in association with the Ministry of Planning and International Cooperation and the Ministry of Municipal Affairs funded the Urban Growth Scenarios for the Hashemite Kingdom of Jordan project to outline sustainable development paths for five Jordanian cities: Amman, Irbid, Mafraq, Russeifa, and Zarqa (CAPSUS, 2018). The project developed urban growth scenarios to compare and understand the "possible futures" of the cities for 2030 through numerical information and also assessed the advantages and disadvantages of the various combinations of public policies, projects, and conditions. Policies (covering for example land use, transportation, energy, and waste management) were organised in a set of three scenarios: a Business-as-usual scenario (BAU scenario) that follows the historical growth of the city; a Moderate scenario that adheres to the city's Master Plan and assumes that projects planned for each city will take place; and a Vision scenario that couples compact urban growth policies with a more ambitious implementation of projects and policies. 
The study found that compact growth policies ${ }^{5}$ yield the highest environmental, social, and economic benefits. Overall economic savings ranged from 12 to $49 \%$ when comparing compact growth development against the expansion of the BAU scenario, and increased to 20 to $54 \%$ in the Vision scenario. This is true for all except Russeifa, where all scenarios have a compact urban form because of the natural restrictions on expansion in the area (CAPSUS, 2018: 99). The Vision scenario can potentially increase the population that could walk to work by $38 \%$, reduce the annual costs of providing municipal services by $20 \%$, and prevent $1.1 \mathrm{MtCO} e q$ per year in the five cities, compared to the BAU scenario. This results in a $4 \%$ reduction in annual greenhouse gas emissions in Jordan (CAPSUS, 2018: 2).

\section{Greening housing}

There has been a lot of literature on the potential energy and water savings from greening housing in Jordan, which could generate savings for households (Alkhalidi \& Aljolani, 2019). In Jordan, residential buildings make up $72 \%$ of total buildings and is the fastest growing subset. In 2018 , the sector accounted for $46 \%$ of total electricity use and $21.5 \%$ of Jordan's total energy consumption (IBRD \& World Bank, 2020: 3). The housing sector also accounts for a large proportion of Jordan's water use (in 2013 it accounted for $42 \%$ of total water consumption - Alkhalidi \& Aljolani, 2019). In Jordan the housing sector constitutes one of the most important sectors in the economy, as it plays a significant role in the creation of wealth in the country, contributing on average $7.2 \%$ of GDP to the economy over the 2004-2015 period and a third of the growth capital formation. It also created a number of jobs in the formal and informal sector and was an important contributor to government revenues at both national and local levels (Hamilton et al., 2018: i).

The CAPSUS study (2018: 64) on future growth of Jordanian cities finds that enforcing a Green Building Code in 90\% of new houses built in Amman between 2015-2030 has the second highest impact on cost savings to the Municipality of the 6 policy levers explored. Costs of municipal services are reduced by $3 \%$ if almost all new dwellings are built according to the code - these savings are mainly through a $6 \%$ reduction in overall housing water demand, as providing water to Amman's residential properties accounts for $50 \%$ of the municipal service costs. Overall, if green building codes are enforced for $90 \%$ of the new housing units in Jordan, by 2030 the energy consumption per housing unit will be 11,686 kWh per year compared to 12,724 kWh per year under the BAU scenario, an $8 \%$ reduction. Water consumption will be $330 \mathrm{~m} 3$ per unit per year compared to $518 \mathrm{~m} 3$ per unit per year under the BAU scenario, a significant $36.3 \%$ reduction (CAPSUS, 2018: 23; Hamilton et al., 2018: 46). Making the Green Building Code mandatory has the potential to save $1 \%$ of the total energy consumed in Jordan (CAPSUS, 2018: 100). Less energy consumption and water consumption directly reduces electricity and water bills paid by the households. Furthermore, it means that there will be substantial savings in the municipal budget in energy and water provision, which are also passed to the households as further savings. This is another way to reduce the "hidden costs" which are not directly paid by the developers, but which will be borne by the government and households eventually (Hamilton et al., 2018: 46).

Residential energy efficiency retrofit provides a solution that acts on both climate and economy being labour intensive and creating a large number of skilled and semi-skilled jobs (IBRD \& World

\footnotetext{
${ }^{5}$ The OECD explains that there are three characteristics of a compact city: dense and proximate development patterns; urban areas linked by public transport systems; and accessibility to local services and jobs. Taken from https://www.oecd.org/cfe/regionaldevelopment/50524895.pdf [accessed 05/08/2021]
} 
Bank, 2020). It's seen as a significant economic stimulus opportunity for Jordan's post-Covid-19 recovery - with an estimated average energy saving of $44 \%$ across three types of Jordanian residential building (IBRD \& World Bank, 2020: 3). Fuel poverty is directly addressed by improving the energy efficiency of dwellings - as making buildings more efficient can reduce bills, and enables occupants to be more thermally comfortable for the same bill expenditure (IBRD \& World Bank, 2020: 4). The note by IBRD and World Bank (2020: 3) on residential energy efficiency retrofit in Jordan also references that "Energy efficiency creates 11.9 new jobs per USD 1 million spent". This is taken from a paper on building energy retrofit in Oman, and is slightly misleading, as the paper actually calculates that 11.9 new job-years are created for every USD 1.0 million invested in building energy retrofit - a job-year is one year of work for one person (Krarti \& Dubey, 2017). Krarti and Dubey (2017) calculate that these jobs are split between 7.0 direct jobs and 4.9 indirect jobs. The paper also calculates that for the case of Oman, up to 41,376 new job-years can be created when retrofitting the existing residential building stock, and this can be expanded to 143,633 job-years when the entire building stock is considered (residential, commercial and government) (Krarti \& Dubey, 2017).

\section{Energy savings, security and domestic manufacturing potential}

Jordan has few fossil-fuel resources of its own, in 2018 it imported $94 \%$ of its energy needs, which constitute nearly $10 \%$ of the country's GDP, leaving it vulnerable to variations in fuel prices (OECD, 2016; Abu-Rumman et al., 2020). The reductions in costs of renewable energy technologies in the last decade provides a compelling argument for greater investment in renewables from purely a cost perspective. Recent submissions in Jordan yielded bids as low as USD $0.03 / \mathrm{kWh}$ (kilowatthour). In comparison, the average cost of electricity purchased by National Electric Power Company (NEPCO) in 2018 was USD 0.114/kWh (IRENA, 2021: 29). The cost of electricity purchased from renewable energy averaged USD $0.11 / \mathrm{kWh}$ compared to USD $0.12 / \mathrm{kWh}$ from conventional sources in Jordan in 2018.

Diversification of the energy mix also brings opportunities for job creation and the development of new industries, as well as reducing dependence on electricity imports (IRENA \& ESCWA, 2018). According to IRENA (2021), nearly 300 licensed companies have been established in solar photovoltaics (PV) design, procurement, installation and operation and maintenance (O\&M) in Jordan since 2013, providing full-time employment to several thousands of people. For example, in general, for a $50 \mathrm{MW}$ solar PV plant "a total of 229,055 person-days are needed. O\&M workers are needed throughout the project lifetime, and therefore represent the bulk of the labour requirements $(56 \%$ of the total). Equipment manufacturing $(22 \%)$ and installation and grid connection (17\%) also require significant labour inputs" (IRENA, 2017 cited in IRENA, 2021: 30).

The jobs exist across the value chain in Jordan, including in manufacturing. Jordan has the capacity to manufacture some windfarm components locally, creating jobs and laying the foundation for a future industry (IRENA \& ESCWA, 2018: 8). Most of the job potentials in onshore wind energy would be around construction, production of wind turbines and blades (IRENA \& ESCWA, 2018: 33). However, exact figures on numbers are not available. There is also potential in the development of concentrated solar power (CSP), where at least $30 \%$ (by value) of a project could be manufactured locally. Most of the job potentials in CSP would be around manufacturing of solar field mounting structures and mirrors (IRENA \& ESCWA, 2018: 29). But no specific data was provided on the number of potential jobs. 
The Jordanian Government estimated that renewable energy and energy efficiency projects in Jordan could create around 2000-3000 jobs in remote and less developed areas in Jordan (MEMR, 2016 a cited in OECD, 2016 - note that a pdf of the original reference could not be located). Although further analysis is needed to explore the job potential for Jordan of domestic solar PV or wind-turbine manufacturing.

Of the total "clean technology" jobs in the renewable energy and energy efficiency sectors in Jordan in $2016,71 \%$ were in the electricity, gas, steam, and air conditioning supply sub-sector (excluding utilities), representing roughly 12,913 jobs (EDAMA, 2016). Of these jobs, only $18 \%$ were held by women.

The share of domestic energy sources in primary energy is targeted to grow from $8 \%$ in 2017 to $15 \%$ by 2020 and $40 \%$ by 2025 . Beyond manufacturing of renewable energy technologies, new opportunities for value creation also exist in operation and maintenance, design, engineering and financial services, and development of new solutions such as smart grids and metering. More than 5,000 people are estimated to be working in the supply chain (EDAMA, 2019c cited in IRENA, 2021: 49).

It is estimated that across the Middle East and North Africa (MENA) region, renewable energy sector jobs have the potential to expand from an estimated 542,000 in 2017 to 1.2 million in 2030 and 2 million in 2050, accounting for nearly $30 \%$ of all energy sector jobs (IRENA, 2020d cited in IRENA, 2021: 30).

\section{Green growth potential in the water sector}

Engelmann et al. (2019) provide a unique assessment of green growth in the water sector in Jordan using a diagnostics tool to identify green growth potential for six industries and four business models in the water sector. Their assessment identifies several industries within the Jordanian water sector that have significant potential to embody green growth principles. The six industries were wastewater treatment and reuse, independent water and power producers, energy efficiency solutions for water supply, water information technology, water infrastructure and construction, and water management consulting. Using the green growth diagnostics tool, they compared the industries across 18 green growth indicators (under six criteria) in order to show differences in their green growth potential (Engelmann et al., 2019: 10-11):

- Wastewater treatment, independent water and power producers, and energy-efficiency solutions for water supply attain the highest score. The first two industries score especially high in "resource efficiency" and "low-carbon potential".

- The water information technology industry was found to be the only one with high classification for "first-mover" advantages where investments would be well-targeted since the market is not saturated yet.

- Water consulting scores high on "environmental protection" and "economic added value", but rather moderate in the other categories.

- Water infrastructure scores moderate on "low carbon" and "environmental protection", but shows good potential in social aspects, such as "job creation", and has a high "profitability outlook" and high "demand for its products and services". 
Engelmann et al. (2019: 11) highlight that "the categories of "economic added value", "environmental protection", and "eco-innovation utilization" get high scores in total, which represents the core idea of green growth and a means to achieving it. Furthermore, the highest classification in the indicators of "production of water-efficient technologies", "application of (non-) technical innovations" and "potential for growth and profitability outlook" are fulfilled by almost all of the industries."

\section{References}

Abu-Rumman, G., Khdair, A. I., \& Khdair, S. I. (2020). Current status and future investment potential in renewable energy in Jordan: An overview. Heliyon, 6(2), e03346. https://doi.org/10.1016/j.heliyon.2020.e03346

Acosta, L.A., S. Zabrocki, J.R. Eugenio, R. Sabado Jr., S.P. Gerrard, M. Nazareth, and H.G.H. Luchtenbelt. (2020). Green Growth Index 2020 - Measuring performance in achieving SDG targets, GGGI Technical Report No. 16, Green Growth Performance Measurement Program, Global Green Growth Institute (GGGI), Seoul, South Korea. https://greengrowthindex.gggi.org/wp-content/uploads/2021/01/2020-Green-GrowthIndex.pdf

Alkhalidi, A., \& Aljolani, O. (2020). Do green buildings provide benefits to the residential sector in Jordan? Yes, but.... International Journal of Low-Carbon Technologies, 15(3), 319-327. https://doi.org/10.1093/ijlct/ctz080

CAPSUS. (2018). Urban Growth Model and Sustainable Urban Expansion for the Hashemite Kingdom of Jordan (English). Washington, D.C.: World Bank Group. http://documents.worldbank.org/curated/en/983981555961147523/Urban-Growth-Modeland-Sustainable-Urban-Expansion-for-the-Hashemite-Kingdom-of-Jordan

EDAMA. (2016). Jordan Clean Technology Sector Report, EDAMA. https://edama.jo/wpcontent/uploads/2018/03/Clean-Technology-Sector-Statistics-Report.pdf

Engelmann, J., Al-Saidi, M., \& Hamhaber, J. (2019). Concretizing green growth and sustainable business models in the water sector of Jordan. Resources, 8(2), 92. https://doi.org/10.3390/resources8020092

Envision Consulting Group (Enconsult) Jordan. (2011). Towards a Green Economy in Jordan: A Scoping Study. Commissioned by UNEP in partnership with The Ministry of Environment of Jordan. https://www.greengrowthknowledge.org/national-documents/towards-greeneconomy-jordan-scoping-study

Global Green Growth Institute (GGGI). (2020). The Promise of Green Growth: A Pathway to Prosperity while Achieving National and Global Ambitions. GGGI TECHNICAL REPORT NO. 15. Seoul: GGGl. https://gggi.org/report/https-gggi-org-site-assets-uploads-2020-12the-promise-of-green-growth_web_page-view_1dec-pdf/

Gouldson, A., Sudmant, A., Khreis, H. \& Papargyropoulou, E. (2018). The Economic and Social Benefits of Low-Carbon Cities: A Systematic Review of the Evidence. Coalition for Urban Transitions. London and Washington, DC. http://newclimateeconomy.net/content/citiesworking-papers

Hakim, L., Hasna, Z., Le Borgne, E., Ranade, M., Aisa Otin, C., Van Den Berg, C., Huenteler, J.T., Moubarak, A.S. \& Jellema, J.R. (2017). Jordan economic monitor spring 2017: The green economic boost (English). Washington, D.C.: World Bank Group. 
http://documents.worldbank.org/curated/en/114741497625111236/Jordan-economicmonitor-spring-2017-the-green-economic-boost

Hamilton, E., Mints, V., Acero Vergel, Jose L., Ababsa, M., Tammaa, W., Xiao, Y., MolfetasLygkiaris, A. \& Wille, R.J. (2018). Jordan - Housing Sector Assessment - Housing Sector Review (English). Washington, D.C.: World Bank Group. http://documents.worldbank.org/curated/en/855101555960778525/Jordan-Housing-SectorAssessment-Housing-Sector-Review

International Bank for Reconstruction and Development (IBRD) \& World Bank. (2020). BUILDING BACK GREEN: Energy Efficiency Retrofit Programme and Certification Scheme for Existing Residential Buildings in Jordan. Washington, D.C.: IBRD \& World Bank. http://documents.worldbank.org/curated/en/553861617183880008/Building-Back-GreenEnergy-Efficiency-Retrofit-Program-and-Certification-Scheme-for-Existing-ResidentialBuildings-in-Jordan

IRENA (2021), Renewable Readiness Assessment: The Hashemite Kingdom of Jordan, International Renewable Energy Agency, Abu Dhabi. http://www.indiaenvironmentportal.org.in/files/file/IRENA\%20RRA\%20Jordan\%202021.pdf

IRENA \& ESCWA. (2018). Evaluating renewable energy manufacturing potential in the Arab region: Jordan, Lebanon, United Arab Emirates, Abu Dhabi: International Renewable Energy Agency. $\quad$ https://www.irena.org/publications/2018/Oct/Evaluating-renewable-energymanufacturing-potential-in-the-Arab-region

Krarti, M., \& Dubey, K. (2017). Energy productivity evaluation of large scale building energy efficiency programs for Oman. Sustainable Cities and Society, 29, 12-22. https://doi.org/10.1016/j.scs.2016.11.009

Kompas, T., Pham, V. H., \& Che, T. N. (2018). The effects of climate change on GDP by country and the global economic gains from complying with the Paris climate accord. Earth's Future, 6(8), 1153-1173. https://doi.org/10.1029/2018EF000922

Ministry of Environment. (2017). A National Green Growth Plan for Jordan, Amman, Hashemite Kingdom of Jordan. https://www.greengrowthknowledge.org/project/gggi-jordan-nationalgreen-growth-plan

OECD. (2016). OECD Clean Energy Investment Policy Review of Jordan. Green Finance and Investment, OECD: Paris. http://dx.doi.org/10.1787/9789264266551-en

World Bank. (2010). Achieving Sustainable Development in Jordan - Country environmental analysis (English). Washington, D.C.: World Bank Group \& USAID. http://documents.worldbank.org/curated/en/315631468284337239/Jordan-Countryenvironmental-analysis

World Bank Group. (2016). Hashemite Kingdom of Jordan Promoting Poverty Reduction and Shared Prosperity: Systematic Country Diagnostic. World Bank, Washington, D.C.: World Bank. https://openknowledge.worldbank.org/handle/10986/23956 


\section{Suggested citation}

Price, R.A. (2021). Evidence on the advantages of low carbon growth in Jordan. K4D Helpdesk Report 1035. Institute of Development Studies. DOI: 10.19088/K4D.2021.117

\section{About this report}

This report is based on six days of desk-based research. The K4D research helpdesk provides rapid syntheses of a selection of recent relevant literature and international expert thinking in response to specific questions relating to international development. For any enquiries, contact helpdesk@k4d.info.

K4D services are provided by a consortium of leading organisations working in international development, led by the Institute of Development Studies (IDS), with Education Development Trust, Itad, University of Leeds Nuffield Centre for International Health and Development, Liverpool School of Tropical Medicine (LSTM), University of Birmingham International Development Department (IDD) and the University of Manchester Humanitarian and Conflict Response Institute (HCRI).

This report was prepared for the UK Government's Foreign, Commonwealth and Development Office (FCDO) and its partners in support of pro-poor programmes. Except where otherwise stated, it is licensed for non-commercial purposes under the terms of the Open Government Licence v3.0. K4D cannot be held responsible for errors, omissions or any consequences arising from the use of information contained in this report. Any views and opinions expressed do not necessarily reflect those of FCDO, K4D or any other contributing organisation.

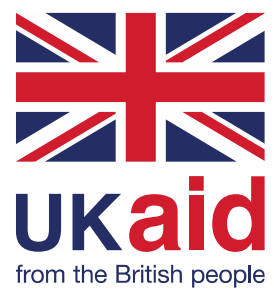

(c) Crown copyright 2021. 